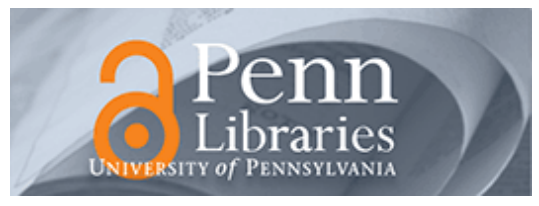

University of Pennsylvania

ScholarlyCommons

\title{
A Badge of Honor not Shame: An AfroLatina Theory of Black- imiento for U.S Higher Education Research
}

Amalia Dache

University of Pennsylvania, adache@upenn.edu

Jasmine Marie Haywood

Christina Mislán

Follow this and additional works at: https://repository.upenn.edu/gse_pubs

Part of the Education Commons

\section{Recommended Citation}

Dache, A., Haywood, J. M., \& Mislán, C. (2019). A Badge of Honor not Shame: An AfroLatina Theory of Black-imiento for U.S Higher Education Research. The Journal of Negro Education, 88 (2), 130-145. Retrieved from https://repository.upenn.edu/gse_pubs/556 


\title{
A Badge of Honor not Shame: An AfroLatina Theory of Black-imiento for U.S Higher Education Research
}

\author{
Abstract \\ The ways in which U.S. scholars and researchers of higher education conceptualize "race" shapes inquiry \\ and ultimately knowledge creation and dissemination of scholarship, research, and policy contributing to \\ the U.S. Latinx education pipeline. \\ This conceptual study addresses the symbolic violence of what "passing for White" as Latinxs mean for \\ studies of colleges and universities, and how centering our African and Black identities calls these \\ manifestations into question. The focus of this study is to juxtapose themes in the U.S. higher education \\ literature, to the experiences of AfroLatina scholars demonstrating shortcomings of "passin' for Latinx," \\ which they construct as the under-theorization of the role U.S. anti-Blackness and Blackness plays in the \\ construct of U.S. Latinidad. Therefore, a conceptual framework of Black-imiento is provided that can help \\ expand the Latinx construct, future research, policy, and practice. \\ Disciplines \\ Education
}




\title{
A Badge of Honor not Shame: An AfroLatina Theory of Black-imiento for U.S Higher Education Research
}

\author{
Amalia Dache \\ University of Pennsylvania \\ Jasmine Marie Haywood Lumina Foundation \\ Cristina Mislán \\ University of Missouri
}

The ways in which U.S. scholars and researchers of higher education conceptualize "race" shapes inquiry and ultimately knowledge creation and dissemination of scholarship, research, and policy contributing to the U.S. Latinx education pipeline.

This conceptual study addresses the symbolic violence of what "passing for White" as Latinxs mean for studies of colleges and universities, and how centering our African and Black identities calls these manifestations into question. The focus of this study is to juxtapose themes in the U.S. higher education literature, to the experiences of AfroLatina scholars demonstrating shortcomings of "passin' for Latinx," which they construct as the under-theorization of the role U.S. anti-Blackness and Blackness plays in the construct of U.S. Latinidad. Therefore, a conceptual framework of Black-imiento is provided that can help expand the Latinx construct, future research, policy, and practice.

Keywords: AfroLatinx, Black liberation, higher education

\section{INTRODUCTION}

Violent White supremacy is being deployed through White-passing U.S. Latinx ${ }^{1}$ bodies, evident in cases where the executioners passed for White but claimed a Latinx heritage. The killings of Trayvon Martin and Philando Castile and the presence of Latinx White supremacists in the Charlottesville protests (Garcia, 2015; Haywood, 2017a; Rosario, 2017) are examples of such cases. In response to this physical and deadly violence, as three Afro-Latina scholars, the authors respond with a conceptual study centered on Blackness within U.S. higher education Latinx scholarship. The study addresses the symbolic violence of what "passing for White" as Latinxs means for studies of education, and how centering our African and Black identities calls these manifestations into question.

As race scholarship evolves across disciplines, it is essential to address how White supremacy functions within constructions of race-making within U.S. Latinidad, or Latinx identity, and how these constructs have pushed us to question how Latinxs (Cruz-Janzen, 2001) are being studied within the field of U.S. higher education. Latinxs from the Caribbean, such as Cuban, Dominicans, Puerto Ricans and Latinxs from Central and South America that had a transatlantic slave trade history, are part of the African diaspora. Therefore, the ways in which U.S. scholars and researchers conceptualize "race" shapes inquiry and ultimately knowledge creation and dissemination of scholarship, research, and policy contributing to the U.S. Latinx education pipeline. It begins from the premise that race is a social construction and undergirded by political-economic forces that are complex and global (Omi \& Winant, 1986). In particular, this conversation aims to contribute to a larger body of race scholarship that has examined the particularities of the construction of U.S. Latinidad and its relationships to constructs of Blackness (Delgado, 2009). Furthermore, the focus of this article is to juxtapose the higher

\footnotetext{
${ }^{1}$ The term Latinx is used instead of Latino, Latina/o, and Latin@ within the literature. We employ Latinx in solidarity with making visible the spectrum of gender identities within this U.S. ethnic community.
} 
education literature, more specifically empirical studies that examine the experiences of Latinxs in postsecondary contexts, to the experiences of AfroLatinx scholars/educators. The authors demonstrate shortcomings of "passin' for Latinx," which we construct as the under-theorization of the role U.S. anti-Blackness and Blackness plays in the construct of U.S. Latinidad. This racial theorization is wholly absent within Latinx higher education scholarship. Therefore, a conceptual framework of Black-imiento is provided that can help expand the Latinx construct, future research, policy, and practice.

In Fordham's (2010) groundbreaking article Passin' for Black: Race, Identity, and Bone Memory in Postracial America, she contends that "passin' for Black" is, "strange, yet so familiar as to be taken for granted" (p. 6). Passin' for Black is a collective process in which a range of phenotypical self-identified U.S. Black individuals perform Blackness and where White fathers are denied, denying the legacies of violence against Black enslaved women (Fordham, 2010). Passin' for Black is not synonymous with an identification as biracial or multiracial, rather it exemplifies how Blackness is uplifted as a source of pride rather than something to be ashamed of. Passin' for Black draws on the collective knowledge and theories of Pan-Africanism and Black Consciousness (Biko, 2017; Ndaba et al., 2017) and is a dialectical conversation with our ancestors and future imaginaries. As such, the authors aim to extend Fordham's framework on the performance of Blackness to interrogate what it means to be Afro-Latinx in the U.S. and its institutions of higher education. We are advancing a theoretical framework that critically analyzes Latinidad by incorporating a transnational lens to explore what Fordham calls "zones of ambiguity" (p. 25). "Passin' for Latinx" does not deny White fathers-as Fordham (2010) argued in Passin' for Black - rather it privileges them while ignoring and rejecting Blackness (or Black ancestral mothers). It is important to note, however, that Blackness does not refer to phenotype solely, but more the historical, political, social, and cultural allegiances to Black thought (Biko, 2017). As Shelby (2005) stated of Black solidarity, it is "a commitment to defeating racism, to eliminating unjust racial inequalities, and to improving the material life prospects of those racialized as 'Black,' especially the most disadvantaged" (p. 4).

Furthermore, passin' for Latinx can perpetuate White supremacist thinking through "semantic moves or strategically managed propositions" (Bonilla-Silva, 2010a, p. 57) within a discourse of blanquemiento. The concept of blanquemiento, also known as whitening in the Spanish Caribbean and Latin America, influences Latinxs and people of Latin decent within and outside of the U.S. to distance themselves from their African ancestry and take-up White supremacist thinking, practices, and behaviors (Duany, 2005). As such, there is a need to privilege and incorporate a theory of Black-imiento into dialectics of Latinidad in U.S. higher education scholarship. Due to higher education scholarship masking White Latinx ideology and perpetuating Afro-Latinx subordination that occurs in constructions of Latinidad (Cruz-Janzen, 2001), the aim is to remove the mask and bring Afro-Latinx educational experiences to the surface.

\section{THE EXCLUSION OF BLACKNESS IN THE HIGHER EDUCATION RESEARCH ON LATINXS}

Numerous scholars have explored the experiences of Latinx students (Acevedo-Gil, 2018; Dache-Gerbino, Kiyama \& Sapp, 2018; Rios-Aguilar \& Kiyama, 2012), faculty in postsecondary settings. Studies address factors of college access, enrollment, and retention through postgraduate education (Fernandez, 2002; Nuñez \& Kim, 2012). In particular, higher education scholars have provided insight with studies on the postsecondary inequities between Latinxs and other racial groups (e.g. Solórzano, Villalpando, \& Oseguera, 2005; Yosso, Smith, Ceja \& Solórzano, 2009; Yosso, 2006). As a result of this treatment of Latinxs as a monolithic race, group differences are overlooked at the expense of comparing Latinx students to their White counterparts. Researchers have also examined the gender gap within the Latinx population (e.g. Pérez, 2014; Sáenz \& Ponjuan, 2009), the self-authoring process for Latinxs (Torres \& Baxter Magolda, 2004; Torres \& Hernandez, 2007) Latinx undocumented students (Bastida et al., 2007; 
Pérez Huber, 2010; Pérez Huber \& Malagón, 2006; Olivas 2004), and first-generation Latinx undergraduates (Huerta \& Fishman, 2014; Saunders \& Serna, 2004). More recently, scholars have even explored Latinx ethnic subgroups in higher education (Nuñez \& Crisp, 2012; Nuñez et al., 2008). There has also been some attention to Chicanxs within studies of the educational pipeline (Yosso, 2006). Nevertheless, not one of the proliferation of studies on Latinxs in higher education exclusively examines Afro-Latinxs or the unique experiences of Latinxs that center and assert their Black or African heritage, with the exception of Haywood's (2017b) study. Accordingly, the vast majority of higher education scholarship conflates Latinxs in higher education to either a racial or ethnic identity that is limited in terms of existing within a U.S. Black/White racial construction.

A few studies on Latinx students within experiences of college access and choice have complicated the raced, gendered, and classed experiences of Latinx students (Sapp, Kiyama \& Dache-Gerbino, 2016). These research inquiries include understanding violence within urban secondary schools as a product of symbolic violence (Kiyama, Harris \& Dache-Gerbino, 2016, 2016) and how Latinx concentrated urban schools are recruitment targets of for-profit postsecondary institutions (Dache-Gerbino, Kiyama and Sapp, 2018). However, even studies on Latinx students gendered and classed identities would benefit from exploring the racialized nuances of their experiences, ultimately making the inquiry more intersectional. This more fully theorized approach applies to studies of Latinx faculty as well.

The area of Latinx faculty is critical to this study since authors are post-PhD and two are in faculty positions. Higher education scholars have explored the racialized experiences of faculty (Urrieta, Mendez, \& Rodriguez, 2015), barriers to their success (Delgado Bernal \& Villalpando, 2002), their race-related service (Baez, 2000), and recruitment and retention (Ponjuan, 2011) of faculty in higher education. While the examinations of Latinx faculty have been disaggregated by gender (Castellanos \& Jones, 2003); there is almost no scholarly attention given to Latinx ethnicity within U.S. race-making. This leads to a monolithic and simplistic view of how Latinx faculty experience race and racism in the U.S. academy. Moreover, while Afro-Latinx scholars have published personal accounts of their marginalized experiences, both inside and outside of the academy (Bonilla-Silva, 2010b; Cruz-Janzen, 2007; Jorge, 1979; Torres-Saillant, 2010), it is not within the higher education literature. Thus, the distinct and unique experiences of AfroLatinx faculty are virtually invisible within the extant literature.

\section{LITERATURE ON U.S. LATINIDAD}

The fluidity of Latinidad has been analyzed across and within disciplines (Duany, 1996; Rodriguez, 2000; Thomas, 1967). Within the critical race theory (CRT) literature, LatCrit focuses on the racialization of Latinidad and how non-White and White racial ascriptions and ambiguities were constructed within the U.S. The "White cases" (Lopez, 2003, 2006) are central in understanding how Whiteness has functioned within U.S. case law. In the area of Afro-Latinx studies, hyphenating and prefacing Latinx with Afro is central to understanding that a majority of Latinxs are of African descent. Although there are varying historical influences on the different types of Latinidad within the U.S. and broader Latin American context, the authors focus on two strands: Chicanxness and the area of Latinx lynching in order to draw attention to the forming of political identities. The former becomes a model that helps inform our theory on Black-imiento - embracing U.S. Black liberation politics within a Latinx identity. The latter pushes in the direction of U.S. domestic Black racial experiences through the history and association of Black lynching. Through Chicanx studies literature, we are able to imagine what a Black political identity for decedents from the Spanish-speaking Caribbean and Latin American countries with African diasporic histories could look like. This literature review uses seminal work from the areas above, in order to situate our framework of Black-imiento within gaps of U.S. Latinx identity politics in the field of education. 


\section{U.S. Constructions of Whiteness and Latinx Immigration}

Since the concept of race was constructed by colonial powers of patriarchal White supremacy and capitalism, it is necessary to understand similar histories of Whiteness in the U.S. and the Caribbean. Being a White person under U.S. Immigration Law was a prerequisite for U.S. citizenship from 1790-1952 (Lopez, 2006). To become White gave immigrants the ability to naturalize, which had implications for superiority, intelligence, and civility. Whereas the inability to naturalize meant that Whiteness was not granted and therefore implied immorality, deviance, and inferiority. Prerequisite cases in the U.S. shaped negative and positive associations of Whiteness and non-Whiteness for immigrants (Lopez, 2006). Blanquemiento, similar to White assimilationist strategies in the U.S., encouraged Caribbean descendants to disregard their African ancestry in order to embrace interracial relationships with European descendants (Duany, 2005). Since Latinxs have historically been considered off-White, Whiteness became an assimilation variable associated with Latinidad in the U.S. (Cruz-Janzen, 2001; Duany, 2005; Logan, 2010). Furthermore, in the Caribbean a common phrase used to describe interracial progress is adelantar la raza (sometimes referred to as mejorar la raza or 'improve the race' in parts of the Spanish-speaking Caribbean), meaning to advance the race, if you were phenotypically Brown or Black, you were encouraged to reproduce and bare children with Whites in order to lighten the next generation of your family (Cruz-Janzen, 2007). Blanquemiento and adelantar la raza, similar to the pre-requisite cases, conferred positive attributes to Whiteness and negative attributes to Blackness and non-Whiteness. However, there are examples in the U.S. of Latinx collective efforts organizing against the pull toward Whiteness.

\section{The Brown-ing of Chicanxs}

Within the U.S., the racialized politics of identity are present in the histories of Latinxs of Mexican decent. There was a critical shift from discourses of Mexican-Americans embracing assimilation and Whiteness until approximately the 1960s to becoming more radical in challenging state oppression on the West Coast. "Before 1968, leaders of the Mexican community had claimed to be White. After that year, and still to this day, many Mexicans insisted, instead, that they were Chican[x]s, proud members of a Brown race" (Lopez, 2006, p. vii). For decades prior to the 1970s, Mexicans were counted as White on the U.S. Census. For example, "while 42 percent of Latinxs identify themselves as "some other race," 48 percent claim[ed] that they are White" (p. viii). However, Mexicans on the West Coast during the 1960s were inspired by the radical social movements such as the Black Panthers. "The Chican[x] movement heralded the emergence of a new, quintessentially racial politics that sought to turn non-White status into a badge of pride" (Lopez, 2003, p. 2). Lopez (2006) argued that the Mexicans in California, created a new Brown race and that Chicanx identity was both racial and political.

In the Chicanx case one sees that a social justice movement was part of constructing a Brown solidarity that challenged racism and classism toward Chicanxs. It was also a stance toward challenging White-passing assimilationist beliefs and trends that influenced how Mexicans in the U.S. identified. The Chicanx movement strategically combined both racial and class politics, in addressing Chicanx educational conditions, experiences with police violence, and their discrimination in the courts. The radicalism of the 1968 Chicanx social justice movement is a part of a Chicanx ethnic/social identity. In the Afro-Latinx literature, social movements were not necessarily related to the political identities of Afro-Latinxs, although we could argue that the Young Lords founded by Afro-Puerto Ricans in New York City were tied to Black liberation politics as well as decolonization strategies (Ogbar, 2006).

The Chicanx movement and the Young Lords movement are evidence of the intersections between Black and Brown struggles for liberation with the U.S. Delgado (2009) pointedly illustrated in his research on Latinx lynching that Latinxs too were racially tortured U.S. subjects. 
Therefore, the symbol of the noose in this article can be associated with constructions of U.S. Blackness. The connections of U.S. history and the lynching of Latinxs makes the plight of U.S. Latinxs closely aligned with U.S. Blacks, while acknowledging their differences as well. Delgado (2009) revealed that it is due to ahistoricism and English language dominance that much of the history of Latinx lynching was not known to Latinx communities. Furthermore, Delgado provides more evidence of the power of White-passing assimilation within the U.S as factors leading to the silencing of this history. The authors concur with Delgado that Spanish language is denigrated in the U.S. and policies against Spanish-language speaking in the workplace and schools are assimilationist policies which are part of White American cultural supremacy, contributing to Latinx inaccessibility to historical documents. However, it is further argued that another possibility related to the lack of knowledge regarding Latinx lynching history may be the semantic moves (Bonilla-Silva, 2010a) of Latinx anti-Blackness, and a deliberate separation from a history that aligns Latinxs closely with African Americans.

\section{PASSIN’ FOR BLACK: A BADGE OF SHAME OR HONOR?}

In Dillard's (2010) endarkened feminist epistemology, she explores the "possibilities of narrative representations called life notes" (p. 664) that the authors employ as methodology in this study. Commonly seen in narrative research, life notes are defined as "constructed personal narratives such as letters, stories, journal entries, reflections, poetry, music, and other artful forms" (p. 664). Just as life notes may hold "unedited, uncensored woman talk" due to the lack of African American woman's theory in mainstream research, it is suggested that life notes are a useful tool for theorizing about a largely unspoken identity (Bell-Scott, 1994, p. 13). Similarly to African American feminist scholarship, the literature on Afro-Latinidad within the U.S. is absent as a body of research from the larger canon of Latinx studies. Dillard argued that African American women's voices “embodied in life notes can be seen as specialized bodies of knowledge which, while legitimate and powerful, have been excluded from the reified bodies of knowledge and epistemological roots undergirding most social science research literature and practice" (p. 664). Therefore, this article uses the life notes of three Afro-Latinas to privilege the educational experiences (both formal and informal) as "evidence of things not seen" (Dillard, 2010), which equate with our hybrid Black and Latina racialized identities. According to Dillard, personal narratives can elucidate a Brown and Black feminist epistemology often invisible in mainstream scholarship. Here, our personal testimonies center Afro-Latina ways of knowing. What follows are three life notes from Afro-Latina Ph.Ds. that highlight the complexity, politics, and marginalization that comes along with being Afro-Latina, in addition to the unwavering commitment to centering an Afro-Latinx identity and disrupting anti-Black notions of Latinidad.

\section{Narrative no. 1: En la oscura ventana de [In the dark window of] Academia}

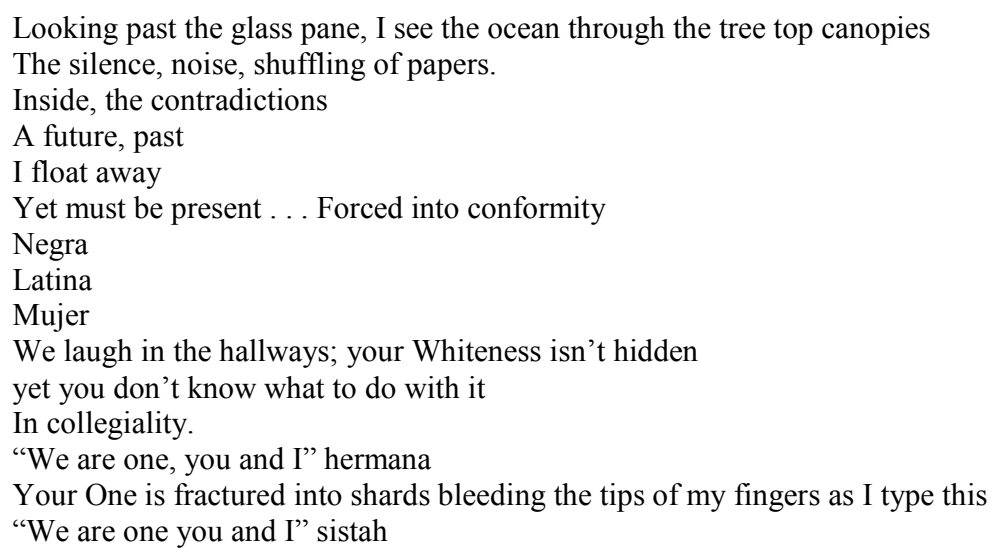


But, we too are fractured and the glue that binds us

Slips to

El monte, palo

Orishas

Omitted in your Jesus

Erasure

Research

Teaching

Service

Subtract

Soul

Spirit

Ancestors

Mi Ochun

Mi Yemaya

en mi piel carmelita en mi historia transnacional

I emerge

From poisoned waters,

Unscathed.

There have been several moments in my academic life where my salient African ancestry and Blackness seemed to conflict with my Latina identity to other Latinxs. Starting my first tenure track position at the University of the Midwest [pseudonym] and being connected to a Latinx organization on campus proved quite telling. I recall being introduced via e-mail to a Latina faculty member who recommended we meet for lunch at one of the many local restaurants within walking distance to campus. We had never met face-to-face, and as usual, meeting for the first time began something like this: you walk in, scan the room to find someone that may fit your mental description of how they may look. Since the city I reside in has a Latinx population that is less than $4 \%$, it would be easy to spot a woman of color who based on my own experiences within Latinidad, ranged in possibilities of skin tone, phenotype and hair texture. I walked into the restaurant and there was one woman sitting alone with dark hair and light brown/beige skin, her sitting alone gave me permission to walk over, and she also fit my possible mental pictures, which were almost endless.

When I sat down we engaged in conversation in English, we shook hands and we sat facing each other, where we continued our conversation in English. My first questions to her were to tell me about her experiences as a Latina faculty member at our campus, and she began to tell me about how she was adjusting, having been a faculty member for four years and nearing her tenure review. It was her turn to ask questions of me it seemed, and her first question was - as if I already saw it coming with her glances at my large natural curly-kinky hair for the last few minutes - "What is your Latinx heritage, where are your parents from?" Something sank in the pit of my stomach, this feeling was all too familiar to me in encountering Latinxs all of my life who were lighter-skinned Puerto Rican classmates, that easily discounted my Latina-ness due to my darker skin and curly-kinky hair and would ask if I was "una moja [derogatory for Black girl]." I responded quickly, as I snapped out of my flashback - although I should have responded much more slowly, much more intentionally, "I am Cuban, soy Afro-Cubana, naci en Cuba y mis padres y hermanos y yo imigramos a los Estados Unidos durante el mariel." I felt as if breaking into Spanish would prove to this Latina that I too was as Latina as she was. Although this felt like a moment in a courtroom where the last piece of evidence sealed what would be the likely verdict of the jury to free an innocent client, it was reductive and made me feel small. Why? Because upon reflection, I see clearly that her first questions to me related to my Latina identity or rather proving my Latina identity, whereas my first questions to her related to her transitions as a Latina faculty member, having already accepted that she was Latina. Her subquestion regarding my parentage and the fact that she asked about my heritage, stemmed from possible assumptions that I had a Black or African American parent, and that I was born in the 
U.S., not a native of a Latin American or Spanish-speaking Caribbean country. Again, these questions were connected to a dark and horrific history of White and White-approximating Latinxs shaming their darker-skinned kin (Cruz-Janzen, 2001). Although I can trace the history, I can't tell you that it felt comfortable or that I felt connected to this Latina or her Latinidad at any point of our conversation. That was the first and last meeting I had with her and needless to say, I did not join the Latinx organization at my university. Instead, I did become an affiliate in the Black Studies Department and the Afro-Romance Languages Institute.

\section{Narrative no. 2: “But you aren't Black (?)": Navigating my "Blackness" in a Binary World}

\section{“What are you? Black or White?; Your grandmother is Black?!” (Voices from my childhood)}

I spent much of my childhood and adolescent years grappling with these questions and statements posed by childhood friends and strangers alike. As an adult, I am expected to continue to have an answer to this binary question about Whiteness and Blackness. In the academy, I am no less judged by such standards. I often confront raised eyebrows by interrogators when I say I am a Puerto Rican born and raised in the Deep South-I own my Blackness. When I show friends pictures of my family, they are dismayed to see my Black grandmother. I know this confusion well. A Puerto Rican who owns her Blackness? Here's the next statement and question: "But you aren't Black (?)" It is uncomfortable feeling to be told you are not something, a "thing" based on presumptions about U.S.-centered notions of Blackness. Some years ago, still studying for my Ph.D., I found myself in a heated debate about the symbolic representation of President Barack Obama. Despite my criticisms of Obama's policies, I found myself arguing with a White male about the importance of Obama's presence. This colleague "reminded" me that because I am not Black, I could not proceed to know how Black communities perceived Obama's presidency. Now, I was willing to admit my argument was flawed because of a variety of factors. For instance, maybe Obama's presidency has meant nothing for Brown and Black folks materialistically? Many marginalized people still died at the hands of the State. But never once did I think that my non-Blackness would be the basis of this flaw. See, for my White colleague, my Puerto Rican-ness and lighter complexion separated me from the racial category of "Black" in the U.S.

Since I am situated within a specific socio-historical context, I know that such notions about race in the United States frequently are centralized on contradiction. The Deep South has always been predicated on the ideology of the one-drop rule. One drop of African blood, and you are Black. This is the consequence of slavery and the foundation upon which Jim Crow politics was born. Yet, phenotype matters. If one does not "look" Black, then their Blackness can be stripped away, or the very least questions abound. These questions often come from White and Black Americans alike, who believe my racial ambiguity and Latinxness constitute a separate category.

But questions about the intersections between Latinxness and Blackness have not just come from U.S. American individuals. "We are Latinas?" "Why don't you speak Spanish? I'm not Black, I am. ..." This latter statement is often followed by a national identity: I am not Black, I am Dominican, and so forth. So many times have I heard these questions and statements from Latinx individuals. When I first arrived at my new academic institution, I was invited to an event celebrating Latinx heritage. Here, we were asked to walk in a line and wave the flag of our national identity. Nationalism has always made me uncomfortable, but I do appreciate the celebration of an identity that is often perceived as associated with a Brown "invasion." While we uncomfortably and dumbfoundedly waved our flags, I began to ask other questions: what about the preservation of our Black mothers? See, all too often, we are concerned with the preservation of certain cultural tools, like Spanish. When does a colonial language supersede our mother languages and cultural symbols? To place so much emphasis on a European language and not begin to ask about our native and slave pasts is to reject our Blackness. 
Whereas the one-drop rule in the United States focuses on Blackness (for the purposes of justifying exploitation and subjugation), the one-drop rule of Whiteness has permeated much of Latin America (a consequence of Spanish colonialism and slavery). For much of Latin America, one-drop of Whiteness inevitably places you one step above Blackness. Education, social upward mobility, economic freedom, and other opportunities are more achievable when an individual's Whiteness is more apparent and readily embraced (Telles \& Flores, 2013). Of course, Whiteness (like Blackness) does not always manifest itself in phenotype. Individuals with darker complexions may still claim their "Spanish" ancestry, another way of claiming their Whiteness (Busey \& Cruz, 2017). Or to put it another way, the focus turns to the white masters (our fathers) who raped Indigenous and Black women (our mothers) in the name of conquest. We must call for our scholarly disciplines to expand beyond U.S.-centered definitions of Blackness, and explore what a movement that re-introduces negritude can do for our conceptual understandings of Latin-ness. Maybe, in my case, I must continue to evoke the memory of my Black grandmother.

\section{Narrative no. 3: “One ever feels [her] three-ness—a Latina, a Negra, an American...”}

As a Black Puerto Rican woman, or Afro-Puertorriqueña, my ancestors were a mix of European, African, and Taíno. As a result, my phenotypic features complicate the Black-White binary in the U.S. My caramel-colored skin, thick and frizzy, curly hair, and broad nose are signifiers of the Senegalese blood that runs through my veins. As an Afro-Latina scholar in the Midwest I am constantly in situations in which my identity is being negotiated and (re)constructed. I am incessantly encountering racial microaggressions that take the form of questioning-What are you? Where are you from? Even though the intent of these questions are not usually malicious, they still constantly position me as an alien, not from "here," and serve as a reminder that my physical appearance does not allow me to be neatly categorized into a box.

Two years after moving to the Midwest a White male student at an off-campus event called me a racial slur. It was the first time I had experienced the pain of overt racist name-calling and it was also one of the defining moments in my Afro-Latinidad. From that moment, I made the conscious decision to always center, assert, and unapologetically acknowledge my Blackness in every space that I occupy. Additionally, I committed myself to calling out when Latinxs distanced themselves from Blacks or Blackness in an attempt to strengthen their own racial position. Accordingly, my aesthetic, linguistic, personal, and academic politics all uphold and regard Blackness as a, "badge of honor" (Fordham, 2010). Consequently, I have experienced feelings of exclusion within Latinx communities both inside and outside of the academy. For instance, when I was applying to Ph.D. programs I met with a light-skinned, phenotypically White Latina faculty member from a program I was applying to. This happened to be the first one-on-one meeting I had with a Latina faculty member in my life, so I was undoubtedly looking forward to it. As I sat there and told her why I wanted to get my Ph.D., about my interest in studying Afro-Latinxs, and my future career goals she maintained a stern, solemn, and cold presence. First, she emphasized how small of a population Afro-Latinxs in higher education are and essentially told me that they were not significant enough to justify a study. She then proceeded to suggest that I put off pursuing my Ph.D. and instead pursue full-time work opportunities. At first I could not make sense of my meeting with her. Why would she not support another Latina aspiring to get a doctoral degree? Despite this disappointing and unexpected advice I successfully applied to doctoral programs and got accepted with the support and mentorship of Black female faculty members. The Black women that mentored me told me that my research interest was valid and that I had what it takes to succeed in a doctoral program. They provided me with the strength, confidence, and love that I needed not only to get into a doctoral program but also to make it through the program. In this way, my Black female faculty mentors were my "other mothers," or women who help blood mothers by contributing to mothering duties (Collins, 2005). In contrast to the light-skinned Latina I met with as an aspiring doctoral student 
my Black other mothers continued the long-standing tradition among African descendent women in which they feel accountable for the success of Black children and therefore engage in the longstanding practice of offering an ethics of care that goes beyond interpersonal.

Within the academy, as well as in the Midwest, where I currently live, the Latinx community tends to be Mexican-centric - the Latinx subgroup least likely to identify as Black (Logan, 2010). In turn, I have professionally and personally experienced the deep-seated historical legacy of colorism within the Latinx community. Phenotypically White Latinxs have disregarded me and labeled me as other as a result of my choice to pass for Black. Most of the anti-Black sentiments I have experienced among Latinxs in the academy manifests itself in subtle and seemingly innocent ways - an avoidance of eye contact, interracial distancing (Carbado, 2002), false smiles, or an overwhelming silence when I bring up or call out issues of race. Nevertheless, their connectedness to the ideologies of our Spanish colonizers and White Supremacist beliefs are obvious. My intentional decision to perform Blackness vis-à-vis the research that I do, my untamed kinky curly hair, and my predominantly Black and Afro-Caribbean social circles, among other things, are a testament to the steadfast resistance of African descendant people in the face of multiple oppressions and White supremacy.

\section{CONCEPTUALIZING BLACK-IMIENTO WITHIN LATINIDAD}

The narratives highlighted divulge the experiences of three scholars who identify as AfroLatinas. What these life notes illustrate are Afro-Latina experiences engaging with Latinxs and non-Latinxs who negate and reject Blackness as a cultural marker within Latinidad. As Carbado (2002) suggested, "there are moments in American history when certain Asian Americans and Latin[x]s have attempted to achieve equality by asserting that they are not Black or like Blacks, and/or that they are White" (p. 1310). Carbado calls this phenomenon "interracial distancing," where a minoritized group "adopts a 'civil rights' strategy to distance itself racially and politically from another minority group" (p. 1310). Our life notes demonstrate the various moments in which Latinx individuals have decided to distance themselves from Blackness. For passing Latinxs, Blackness is the quintessential badge of shame. The rejection of African blood as part of an ongoing colonial project in conceptions of Latinidad are directly tied to the way Whiteness has become a badge of honor in Latinx communities. Some exceptions can be made within the Caribbean, for example within the Cuban context. Cuba's sustainability of African and Spanish hybrid spiritual and cultural traditions are evidence of a centering on African-ness. In addition, Cuban revolutionary higher education access policies post 1959, were able to raise illiteracy rates among Black Cubans and flatten class and educational barriers through anticolonial and anti-capitalist approaches to national social progress (De la Fuente, 2001). Yet, intergroup anti-Black racism continue to exist. Drawing from Fordham (2010), these life-note narratives seek to re-frame what it means to "pass for Black" within understandings of what it means to be quintessentially Latinx in the U.S.

It is essential to note that passing for Black tells us more about the performance of racial identity, than the actual phenotype of individuals. In other words, a Latinx can have White, Indigenous, or non-Black phenotypical characteristics, but still be intentional about performing and asserting a Black identity. As Biko (2017) reminds us within the construction of Black consciousness during South African apartheid that emerged to bring together fragmented racial categorizations of people of color (i.e., Blacks, Coloured and Indian):

Being Black is not a matter of pigmentation - being Black is a reflection of a mental attitude. . . .

Merely by describing yourself as Black you have committed yourself to fight against all forces that seek to use your Blackness as a stamp that marks you out as a subservient being. (p. 52)

\section{TENETS OF BLACK-IMIENTO}

In articulating Black-imiento, our intention is to create a conceptual framework that rather than simplifies racial/ethnic identity for U.S. Latinxs, will resist metanarratives of Latinxs as a U.S. racial category that is ahistorical and depoliticized from the U.S. domestic Black-White binary 
paradigm. Furthermore, the authors challenge the covert chasms between Blackness and Latinidad, and put forward three tenets of Black-imiento that can be applied when exploring the educational experiences of Latinxs: (a) Black anti-racist aesthetics; (b) Afro-Latinx historical consciousness and (c) the rejection of a racialized pan-ethnic Latinx label. Although the three tenets build on Fordham's (2010) notion of 'passin for Black,' they have distinctions based on an African history situated within the origins of enslaved Africans in bondage within Latin America and the Caribbean. While these authors argue for a transnational understanding of Afrocentrism and Blackness, it is simultaneously argued for an understanding of U.S. AfroLatinidad as part of colonial histories of domination that emerged similarly and differently from that of U.S. domestic colonial histories.

\section{Tenet 1: Black Anti-Racist Aesthetics}

From a Black-imiento perspective, research centering on Latinxs actively rejects conceptions of Black/White aesthetics that center Whiteness and do not take into consideration phenotype and/or the adoption of an Afro-Latinx identity as it relates to U.S. racism and privilege. In this realm, Black-imiento operates from the premise that there are racialized standards of beauty which perpetuate the mechanisms of racism. Thus, Black-imiento resists adhering to societal norms that encourage altering the natural Black body in an attempt to be viewed as more attractive. Black feminist scholars have problematized the importance placed on having straight hair, a narrow nose, and light skin (Collins, 1990; hooks, 1992, 1993; Hunter, 2005). The consequence of these dominant Eurocentric beauty ideals is a racialized hierarchy that is embedded in physical appearance. As a result, these negative beliefs are internalized and a wide variety of racialized beautification practices (e.g., skin bleaching, the chemical relaxation of hair, the use of colored contacts, etc.) in addition to invasive surgeries (e.g., nose surgery) are normalized and thrust on Black women's bodies.

In the narratives, we all share experiences in which we were racialized based on our appearance. Our experiences demonstrate how we were made to feel not Latina enough in addition to not Black enough at different points in our lives. In this way, skin color and hair texture have unavoidably shaped the quality of our lives and interactions. Consequently, we are constantly forced to decide how to locate ourselves "within a beauty both as a matter of aesthetics and politics" (Tate, 2007, p. 301). Black-imiento seeks to (re)situate, (re)negotiate, and (re)present Blackness within Latinidad. Thus, Black-imiento recognizes that terms such as Indio or trigueno are incited to erase and distance African ancestry, not necessarily solely to be in solidarity with indigenous decolonization politics. Rodriguez (2000) stated that media representations of Latinidad consist of a complexion that is "slightly tan, with dark hair and eyes" (1997, p. 1). Therefore, an ideal White Latinx phenotype is indicative of some combination of European, indigenous, and African ancestry but is still phenotypically distant from African features (Candelario, 2007). Black-imiento is committed to the practice and politics of Black anti-racist aesthetics (Tate, 2007; 2012). Furthermore, it works toward expanding the boundaries of Black and Latinx beauty and advances a positive and more all-encompassing Black and Latinx politics, rather than one that ostracizes lighter-skinned women within the Black community, or that challenges the authenticity of Afro-Latinxs within the Latinx community (Tate, 2007; 2015).

\section{Tenet 2: Afro-Latinx Historical Consciousness}

Centering a political framework of Black-imiento in Latinx higher education scholarship also calls for a historical grounding of Black transnationalism, "a product of consciousness, that is, the conscious interconnection and interlocution of Black struggles across man-made and natural boundaries" (West, Martin, \& Wilkins, 2009, p. 1). The second tenet of Black-imiento, therefore, calls for a historical consciousness that explicitly engages with the work of radical Black and Brown intellectuals across national contexts. As historian Anthony Bogues (2003) suggested, both "continental and diasporic African thinkers begin the tortuous passage of making [their] way back to the horizons of the native/lower-order population left behind" to shed light on the 
colonial or racial condition (p. 12). Furthermore, Black intellectuals begin with history and with a "reclamation announcing the agency of the Black colonized people" (Bogues, 2003, p. 12). Through this form of Pan-Africanism we "seek solidarity among those of African descent" (Ndba et al., 2017, p. 3) within the U.S to those outside of our national borders. We reclaim the history of our ancestors' resistance to further reveal the ongoing relevance of the colonial and racial conditions of those in the U.S. who may be, blindly or with eyes wide open, passing for Latinx.

The early twentieth-century saw the consequences of the Great Migration, where local struggles (e.g., Garveyism, Civil Rights, Chicano movements, the Cuban Revolution, and the Black Power movement) sought to overthrow and restructure the capitalist and racist systems that had shaped the conditions and statuses of African-descended people. In centering historical consciousness within a Black-imiento framework, we seek to re-establish a public memory of these smaller social movements, which intertwined with one another as Afro-Caribbean people moved to other Caribbean nations or northward with southern African Americans to the northern parts of the United States. As such, an engagement with Black or anti-colonial intellectual tradition (Bogues, 2003) would center non-Eurocentric and non-Western voices within Black radical thought.

To recall this public memory of Black transnationalism and reclaim our colonized histories, it is key to highlight two political organizations that challenged twentieth-century racial, colonial, and class politics. The emergence of the Black Panther Party (BPP) and the Young Lords Party (YLP) during the mid- to latter-part of the 1960s revealed the ongoing plight of Brown and Black bodies in United States and elsewhere. The political contributions of the YLP, a Puerto Rican revolutionary nationalist group, born in the 1960s, highlights its close ties to the Black Panther Party. Inspired by a Black power platform, YLP members developed one of the first Afro-Latinx political intersections with the African Diaspora. Furthermore, "was instrumental in theorizing and identifying the structures of racism embedded in the culture, language, and history of Latin America and its institutions" (Fernandez, 2004). In addition to the YLP's support for the independence of Puerto Rico, the organization took on the issues of healthcare, deindustrialization, incarceration, and foreign policy, to name a few (Fernandez, 2004). Centering a historical transnational consciousness within a Black-imiento framework highlights the importance of privileging our Blackness as Afro-Latinxs, recovering it as a badge of honor and not shame.

\section{Tenet 3: The Rejection of a Pan-ethnic Racialized Latinx Label}

In tenet 3 we challenge how White supremacy within U.S. racial categories attempts to collapse ethnic identity to homogenize race. For example, collapsing all Latin American and Caribbean identities into a Latinx category could be understood as Latinxs actually constituting a "race" of people. Although one understands the political nature of Latinxs being understood as a race, it remains undertheorized within the U.S. Black-White binary. Latinxs constituting a race differs from Chicanxs constituting a Brown race due to the Chicano struggle originating in a political, social, and labor movement challenging White supremacy (Lopez, 2006). In this tenet, the authors reject the collapsing of Latinx ethnicity alone, without the nuancing of how U.S. BlackWhite binaries position Afro-Latinxs as Black based on phenotype. Ethnic collapsing is a western hegemonic process, and must be considered within a U.S. racial hierarchy (Bashi, 1998).

Within a U.S. racial hierarchy, minoritized ethnic categories are grouped together (i.e. Latinxs, Asian-Americans) and are "raced" between the Black and White binary (Bashi, 1998). However, they are associated with Whiteness when Latinx identities uphold assimilationist tactics and also when individuals can "pass" phenotypically for White. Phenotype is a major part of the spectrum of assimilation, if Latinxs can pass for "White" then there are assimilationist rewards of socioeconomic and political upward mobility if they buy into Whiteness. Whereas, if Latinxs cannot pass for White, they are not allowed to "pass" for White and as such are thrust into either Black or Brown discourses of Latinidad, which have implications for U.S. upward social and class mobility. 
Racial categories created by the White dominant group such as "Hispanic" and even Latinx (although this term had more support from the Latinx community) are part of a U.S. racial hierarchy (Bashi, 1998). The Latinx term is at times used as a synonym for Hispanic, which focuses on the Spanish colonial ancestry of people of Latin American and Caribbean descent. This is an interesting point, because even in this categorization we can see how Whiteness was privileged over native/indigenous identity and African identity. When racial categories are created within the group (Bashi, 1998), such as the case with Chicanxs, there is a resistance to the dominant group definition (i.e., Hispanic, Latinx). This tenet of Black-imiento, falls within the latter, and challenges the whitening of Latinidad while acknowledging African cultural histories that Latinx histories have kept silent in understanding our educational experiences.

\section{CONCLUSION AND RESEARCH IMPLICATIONS}

Within the U.S. higher education literature, the racialized experiences of African descendant Latinx students and faculty have been largely overlooked or masked. We assert that it is problematic to define Latinxs as a racial group without a contextualization of the influences of the U.S. Black-White binary on the experiences of Latinxs who pass for White (Lopez, 2006), and pass for Black (Fordham, 2010). While there is a limited amount literature in higher education that addresses ethnic differences within the educational attainment of Latinxs (i.e., Cubans, Mexicans), this research too is devoid of understanding how Latinx phenotype makes the experiences of Latinxs students and faculty who pass for White possibly more aligned with White Americans, than with Black Americans (Logan, 2010).

Within the realm of higher education research, the application of a Black-imiento framework and specifically the tenet regarding Black anti-racist aesthetics would result in researchers being mindful of differential racialization (Almaguer, 1994), how phenotype effects racialized experiences and the inclusion of Latinxs' skin tone in study measures. The omission of the role of Latinxs' skin color and phenotype in the postsecondary education literature may lead to a misinterpretation of the needs and experiences of racially diverse students. This omission of the role that race and phenotype might have played in the U.S. educational experiences of Latinxs, which is prevalent in the higher education literature (e.g., Guardia \& Evans, 2008; Torres \& Hernandez, 2007; Yosso et al., 2009), does not paint a full picture of what Latinx students might be experiencing and silences those on the margins such as Afro-Latinxs while privileging the experiences of lighter-skinned or phenotypically White Latinxs.

Our framework of Black-imiento situates U.S. Black and Latinx politics within a transnational framing and thus challenges binaries of mutual exclusiveness. As such, U.S. higher education literature that situates Latinxs as a race or just an ethnicity, needs to be theorized and nuanced from a transnational and African diasporic lens. Our life notes underscore an intellectual effort to reclaim our African ancestry, much like the collective Black and Brown consciousness of the South African Black Consciousness Movement, Black Panther Party, Chicanx movement and Young Lords Party in the mid- to late-twentieth century. Re-visiting the intersection of Brown and Black politics, therefore, reframes what it means to "pass for Black" within identities or Latinidad. As intellectuals, we seek to draw transnational connections between our Latinx and African identities, where a public memory of Latinidad is embedded within African Diasporic politics. The narratives, therefore, attempt to reclaim our lived experiences within Blackness, not outside of it. Furthermore, we intellectually position our lived experiences as a political form of rejection, where the "passin' for White" colonial model is replaced with a "passin' for Black" identity and as such pushes research on Latinxs in higher education to engage in a blackening rather than a whitening of the experiences of Latinxs.

Our theory of Black-imiento refutes the label Latinx as a racial category and thereby challenges research methods that use variables of Latinxs as racial categories in an aggregate manner, collapsing ethnic identity. Furthermore, research that address the qualitatively different experiences of ethnic Latinx identities although have nuance across nationalistic and cultural traditions associated with Latin America and the Caribbean, must engage historical material 
experiences of colonialism and White supremacy in the creation of U.S. racial categories within these post-colonial geographies (Dache-Gerbino, 2017).

We contend that past transnational movements such as Negritude and other pan-African movements inform our theory of Black-imiento and the challenging of the global oppression of Africans and those of us in the Diaspora. This racial and political solidarity is what will further the solidarity of Latinxs within the U.S., functioning under Black-White U.S. binaries. Social movements such as Ferguson and Black Lives Matter, can be better understood as being inclusive to Latinx people if we understand how U.S. domestic Latinxs are part of racial liberation struggles. Politically, Black-imieinto challenges neoliberal U.S. foreign policy in Latin American and the Caribbean, and U.S. domestic immigrant and labor policy impacting African diasporic communities, again which include Latinxs who pass for Black.

The social conditions of Afro-Latinxs in the U.S. has major implications in how scholars study their educational experiences. In timing this piece with the current heightened state violence inflicted on Black bodies across the country, we argue that Black-imiento as a framework may assist in drawing attention to the collective experiences of racism faced by all peoples of African descent living in the U.S. The "zones of ambiguity" (Fordham, 2010) within U.S. racial identity, become less ambiguous when we become part of Black and Brown liberation struggles and use this collective thinking to shape education inquiry which can lead to an improvement in the material conditions of Black and Brown people in the U.S.

\section{REFERENCES}

Acevedo-Gil, N. (2018, October 20). New Juan Crow education as a context for institutional microaggressions: Latina/o/x students maintaining college aspirations. Urban Education, https://doi.org/10.1177\%2F0042085918805152

Almaguer, T. (1994). Racial fault lines: The historical origins of White supremacy in California. Berkeley: University of California Press.

Baez, B. (2000). Race-related service and faculty of color: Conceptualizing critical agency in academe. Higher Education, 39, 363-391.

Bashi, V. (1998). Racial categories matter because racial hierarchies matter: A commentary. Ethnic and Racial Studies 20, 959-968.

Bastida,Y., Briones, C., Cruz, J., Diaz, M., Duarte,Y., Espinosa, P. J., Fonseca, L., Ledesma, L., Pérez, R., Nygreen, K., Ramirez, N.Y., Rodriguez, I., Saba, M., Tapia, D., Velez, V., \& Dominguez Zamorano, N. (2007). Students Informing Now (S.I.N.) challenge the racial state in California without shame ... SIN Verguenza! Educational Foundations, 21, 71-90.

Bell-Scott, P. (1994). Life notes: Personal writings by contemporary Black women. New York: Norton.

Biko, S. (2017). I write what I like. Johannesburg, South Africa: Picador Africa. (Original work published 1978)

Bogues, A. (2003). Black heretics, Black prophets: Radical political intellectuals. New York: Routledge.

Bonilla-Silva, E. (2010a). Racism without racists: Color-blind racism and the persistence of racial inequality in the United States. Lanham, MD: Rowman \& Littlefield.

Bonilla-Silva, E. (2010b). Reflections about race by a negrito acomplejao. In Román, M. J., \& Flores, J. (Eds.), The Afro-Latin@ reader: History and culture in the United States (pp. 445450). Durham, NC: Duke University Press.

Busey, C. L. \& Cruz, B. C. (2017). Who is Afro-Latin@?: Examining the social construction of race and negritude in Latin America and the Caribbean. Social Education, 81, 37-42.

Candelario, G. E. (2007). Black behind the ears: Dominican racial identity from museums to beauty shops. Durham: Duke University Press.

Carbado, D. W. (2002). Race to the Bottom. UCLA Law Review, 49, 1283-1313.

Castellanos, J., \& Jones, L. (2003). The majority in the minority: Expanding the representation of Latina/o faculty, administrators and students in higher education. Sterling, VA: Stylus.

Collins, P. H. (1990). Black feminist thought in the matrix of domination. Blackfeminist thought: 
Knowledge, consciousness, and the politics of empowerment, 138, 221-238.

Collins, P. H. (2005). The meaning of motherhood in Black culture and Black mother-daughter relationships. In Zinn, M. B., Hondagneu-Sotelo, P., Messner, M. A. \& Denissen, A. M. (Eds.), Gender through the prism of difference (pp. 285-295). New York: Oxford University Press.

Cruz-Janzen, M. I. (2001). Latinegras: Desired women - undesirable mothers, daughters, sisters, and wives. Frontiers: A Journal of Women Studies. 22, 168-183.

Cruz-Janzen, M. I. (2007). Madre patria (Mother country): Latino identity and rejections of Blackness. Literacy, Expression and the Language of Resistance, 17, 79-92.

Dache-Gerbino, A., Kiyama, J. M., \& Sapp, V. T. (2018). The dangling carrot: Proprietary institutions and the mirage of college choice for Latina students. Review of Higher Education, 42, 29-60.

Dache-Gerbino, A. (2017). Mapping the postcolonial across urban and suburban college access geographies. Equity \& Excellence in Education, 50, 368-386

Delgado Bernal, D., \& Villalpando, O. (2002). An apartheid of knowledge in academia: The struggle over the "legitimate" knowledge of faculty of color. Equity \& Excellence in Education, 35, 169-180.

Delgado, R. (2009). The law of the noose: A history of Latino lynching. Harvard Civil RightsCivil Liberties Law Review, 44, 297-312.

De la Fuente, A. (2001). A nation for all: Race, inequality and politics in twentieth-century Cuba. Chapel Hill: University of North Carolina Press.

Dillard, C.B. (2010). The substance of things hoped for, the evidence of things not seen: Examining an endarkened feminist epistemology in educational research and leadership. International Journal of Qualitative Studies in Education, 13(6), 661-681.

Duany, J. (1996). Transnational migration from the Dominican Republic: The cultural redefinition of racial identity. Caribbean Studies, 29, 253-282.

Duany, J. (2005). Neither White nor Black: The representation of racial identity among Puerto Ricans on the island and in the U.S. mainland. In Dzidzienyo A., Oboler S. (Eds.), Neither enemies nor friends (pp. 173-188). New York: Palgrave Macmillan.

Fernandez, L. (2002). Telling stories about school: Using critical race and Latino critical theories to document Latino/Latinx education and resistance. Qualitative Inquiry, 8, 45-65.

Fernandez, J. (2004). The Young Lords: Its origins and convergences with the Black Panther Party. Retrieved from http://www.ibiblio.org/shscbch/ribb/lords-origins.pdf

Fordham, S. (2010). Passin' for Black: Race, identity, and bone memory in postracial America. Harvard Educational Review, 80, 4-30.

Garcia, W. (2015). White Latinx racism on the rise: It's time for a serious conversation on Eurodiasporic Whiteness. Retrieved from http://www.Latinxrebels.com/2015/12/21/whiteLatinx-racism-on-the-rise-its-time-for-a-serious-conversation-on-euro-diasporicWhiteness/

Guardia, J. R., \& Evans, N. J. (2008). Factors influencing the ethnic identity development of Latino fraternity members at a Hispanic serving institution. Journal of College Student Development, 49, 163-181.

Haywood, J. M. (2017a). Anti-Black Latino racism in an era of Trumpismo. International Journal of Qualitative Studies in Education, 30, 957-964.

Haywood, J. M. (2017b). 'Latino spaces have always been the most violent': Afro-Latino collegians' perceptions of colorism and Latino intragroup marginalization. International Journal of Qualitative Studies in Education, 30, 759-782.

hooks, b. (1992). Black looks: Race and representation. Boston: South End Press.

hooks, b. (1993). Sisters of the yam: Black women and self-recovery. Boston: South End Press.

Huerta, A. H., \& Fishman, S. M. (2014). Marginality and mattering: Urban Latino male undergraduates in higher education. Journal of The First-Year Experience \& Students in Transition, 26, 85-100. 
Hunter, M. L. (2005). Race, gender, and politics of skin tone. New York: Routledge.

Jorge, A. (1979). The Black Puerto Rican woman in contemporary American society. In AcostaBelen, E. (Ed.), The Puerto Rican woman: Perspectives on culture, history and society (pp. 180-187). New York: Praeger.

Kiyama, J. M, Harris, D. M., \& Dache-Gerbino, A. (2016). Fighting for respeto: Latinas' stories of violence and resistance shaping educational opportunities. Teachers College Record, 118, $1-50$.

Logan, J. R. (2010). How race counts for Hispanic Americans. In Roman, M. J., \& Flores, J. (Eds.), The Afro-Latin@ reader: History and culture in the United States (pp. 471-484). Durham, NC: Duke University Press.

Lopez, I. H. (2003). Racism on trial: The Chicano fight for justice. Cambridge: Harvard University Press.

Lopez, I. H. (2006). White by law: The legal construction of race. New York: University Press.

Ndaba, B, Owen, T., Panyane, M., Serumula, R. \& Smith, J. (2017). The Black consciousness reader. Auckland Park, South Africa: Jacana Media.

Nuñez, A. M., \& Crisp, G. (2012). Ethnic diversity and Latino/a college access: A comparison of Mexican American and Puerto Rican beginning college students. Journal of Diversity in Higher Education, 5, 78-95.

Nuñez, A., \& Kim, D. (2012). Building a multicontextual model of Latino college enrollment: Student, school, and state level effects. The Review of Higher Education, 35, 237-263.

Nuñez, A. M., McDonough, P., Ceja, M., \& Solórzano, D. (2008). Diversity within: Latino college choice and ethnic comparisons. In Gallagher, C. (Ed.), Racism in post-race America: New theories, new directions (pp. 267-284). Chapel Hill, NC: Social Forces.

Ogbar, J. O. (2006). Puerto Rico en mi corazon: The young lords, Black Power and Puerto Rican nationalism in the U.S., 1966-1972. Centro Journal, 18, 148-169.

Olivas, M. (2004). IIRIRA, the DREAM Act and undocumented college student residency. Journal of College and University Law, 30, 435-464.

Omi, M., \& Winant, H. (1986). Racial formation in the United States: From the 1960s to the 1990's. New York: Routledge.

Pérez, D. (2014). Exploring the nexus between community cultural wealth and the academic and social experiences of Latino male achievers at two predominantly White research universities. International Journal of Qualitative Studies in Education, 27, 747-767.

Pérez Huber, L. (2010). Using Latina/o critical race theory (LatCrit) and racist nativism to explore intersectionality in the educational experiences of undocumented Chicana college students. Educational Foundations, 24, 77-96.

Pérez Huber, L., \& Malagon, M. C. (2006). Silenced struggles: The experiences of Latina and Latino undocumented college students in California. Nevada Law Journal, 7, 841.

Ponjuan, L. (2011). Recruiting and retaining Latino faculty members: The missing piece to Latino student success. Thought \& Action, 27, 99-110.

Rios-Aguilar,C. \& Kiyama, J. M. (2012) Funds of knowledge: An approach to studying Latina(o) students' transition to college. Journal of Latinos and Education, 11 (1), 2-16. https://doi.org/10.1080/15348431.2012.631430

Rodriguez, C. E. (2000). Changing race: Latinos, the census, and the history of ethnicity in the United States. New York: New York University Press.

Rosario, R. (2017, August 17). A Charlottesville attacker says 'he isn't racist because he's Puerto Rican.' VIBE. Retrieved from https://www.vibe.com/2017/08/charlottesville-attackerLatino/

Sáenz, V. B., \& Ponjuan, L. (2009). The vanishing Latino male in higher education. Journal of Hispanic Higher Education, 8, 54-89.

Sapp, V. T., Kiyama, J. M., \& Dache-Gerbino, A. (2016). Against all odds: Latinas activate agency to secure access to college. NASPA Journal about Women in Higher Education, 9, $39-55$.

Saunders, M., \& Serna, I. (2004). Making college happen: The college experiences of first- 
generation Latino students. Journal of Hispanic Higher Education, 3, 146-163.

Shelby, T. (2005). We who are dark: The philosophical foundations of Black solidarity. Harvard University Press.

Solórzano, D. G., Villalpando, O., \& Oseguera, L. (2005). Educational inequities and Latina/o undergraduate students in the United States: A critical race analysis of their educational progress. Journal of Hispanic Higher Education, 4, 272-294.

Tate, S. (2007). Black beauty: Shade, hair and anti-racist aesthetics. Ethnic and Racial Studies, $30,300-319$.

Tate, S. (2012). Michelle Obama's arms: Race, respectability, and class privilege. Comparative American Studies: An International Journal, 10, 226-238.

Tate, S. (2015). Black women's bodies and the nation: Race, gender and culture. New York: Palgrave Macmillan.

Telles, E., \& Flores, R. (2013). Not just color: Whiteness, nation, and status in Latin America. Hispanic American Historical Review, 93, 411-419.

Thomas, P. (1967). Down these mean streets. New York: Knopf.

Torres-Saillant, S. (2010). Divisible Blackness: Reflections on heterogeneity and racial identity. In Román, M. J., \& Flores, J. (Eds.), The Afro-Latin@ reader: History and culture in the United States (pp. 453-466). Durham, NC: Duke University Press.

Torres, V., \& Baxter Magolda, M. B. (2004). Reconstructing Latino identity: The influence of cognitive development on the ethnic identity process of Latino students. Journal of College Student Development, 45, 333-347.

Torres, V., \& Hernández, E. (2007). The influence of ethnic identity on self-authorship: A longitudinal study of Latino/a college students. Journal of College Student Development, 48, 558-573.

West, M. O., Martin, W. G., \& Wilkins, F. C. (2009). From Toussaint to Tupac: The Black international since the Age of Revolution. Chapel Hill: The University of North Carolina Press.

Urrieta, L., Méndez, L., \& Rodríguez, E. (2015). “A moving target”: A critical race analysis of Latina/o faculty experiences, perspectives, and reflections on the tenure and promotion process. International Journal of Qualitative Studies in Education, 28, 1149-1168.

Yosso, T. J. (2006). Critical race counterstories along the Chicana/Chicano educational pipeline. New York: Routledge.

Yosso, T., Smith, W., Ceja, M., \& Solórzano, D. (2009). Critical race theory, racial microaggressions, and campus racial climate for Latina/o undergraduates. Harvard Educational Review, 79, 659-691.

\footnotetext{
AUTHORS

AMALIA DACHE is Assistant Professor of Higher Education, at the Graduate School of Education at the University of Pennsylvania, Philadelphia.

JASMINE MARIE HAYWOOD is a Policy Analyst at the Lumina Foundation in Indianapolis, Indiana.

CRISTINA MISLÁN is Assistant Professor of Media Studies, School of Journalism at the University of Missouri.
}

All comments and queries regarding this article should be addressed to adache@upenn.edu 